\title{
A Transformação das Relações Institucionais a Partir Constituição de um Grupo de Encontro Entre Profissionais de Diferentes Áreas do Cuidado e Cuidadores de Bebês Prematuros
}

\author{
Braga, Cláudia Pellegrini; Augusto, Paula; Giorgetti, Marília; Klein, Taiane \\ FMUSP — claudia.pellegrini.braga@gmail.com
}

Introdução a promoção do cuidado aos bebês prematuros hospitalizados e cuidadores, na perspectiva da integralidade e da humanização, exige uma qualidade de relação que ultrapasse as barreiras da atenção centrada em procedimentos e da aplicação de saberes técnicos normatizados. É preciso investir em dispositivos que promovam acolhimento, processos vinculares e escuta ao sofrimento e às necessidades. Assim, como proposta de atenção, criouse um grupo de encontro entre profissionais e cuidadores de bebês prematuros. Objetivos Apresentar cenas-acontecimentos deste grupo, investigando as potencialidades para a produção de um cuidado integral e humanizado e as problemáticas e desafios desta experiência. Método a partir de um relato de experiência, serão apresentadas quatro cenas-acontecimentos do grupo, desenvolvido desde agosto de 2013. a análise e a discussão serão desenvolvidas em diálogo com a perspectiva da integralidade e humanização do cuidado. Resultados o grupo tem frequência semanal e, pela rotatividade das hospitalizações, os encontros e seu formato são acordados semanalmente, adquirindo diferentes caraterísticas. Já teve como objetivo ser um espaço para resolução de dúvidas e problemas, compreensão de técnicas e procedimentos realizados, ampliação do cuidado de si, e troca de experiências. Primeira cena-acontecimento: a fisioterapia apresenta aos cuidadores formas de estimulação dos neonatos, visando o desenvolvimento infantil e o fortalecimento do vínculo entre cuidador e bebê. Segunda cenaacontecimento: a fonoaudiologia dialoga com os cuidadores sobre a importância da amamentação e ordenha - uma das principais demandas dos frequentadores do grupo. Terceira cena-acontecimento: a terapia ocupacional realiza encontro focado no cuidado de si dos cuidadores dos bebês prematuros, realizando abordagens corporais. Quarta cenaacontecimento: agencia-se com uma das cuidadoras seu protagonismo na condução do encontro, apresentando sua experiência de ser mãe e as dificuldades enfrentadas no impacto e no processo de hospitalização. Conclusões: a realização do grupo pôde provocar importantes transformações das relações, garantindo um espaço de escuta das demandas, desejos e sofrimentos dos cuidadores de bebês prematuros e proporcionando um espaço de trocas para os profissionais. Investiu-se na composição de diferentes tecnologias - leves, leve-duras e duras - para a construção do cuidado integral à saúde, e, nesse percurso, os profissionais também puderam entrar em contato com o sofrimento desses cuidadores e afinar seus modos de cuidado, transformando-se. como dificuldades, percebe-se que, por vezes, os profissionais assumem uma postura de ensino-aprendizagem na relação com os cuidadores. Ainda assim, é sensível a mudança no cotidiano e nas relações entre usuário-usuário, usuário-profissional e profissionalprofissional, construindo outras conectividades que ampliam a potência de cuidado e de vida de todos os envolvidos.

Braga, Cláudia Pellegrini; Augusto, Paula; Giorgetti, Marília; Klein, Taiane. A Transformação das Relações Institucionais a Partir Constituição de um Grupo de Encontro Entre Profissionais de Diferentes Áreas do Cuidado e Cuidadores de Bebês Prematuros. In: Anais do Congresso Internacional de Humanidades \& Humanização em Saúde [= Blucher Medical Proceedings, num.2, vol.1]. São Paulo: Editora Blucher, 2014. ISSN 2357-7282

DOI 10.5151/medpro-cihhs-10693 